\title{
CHAOTIC MODERN MEDIA: THE NEED FOR GANDHIAN ETHICS
}

\author{
Pratiyogita \\ Ph.DResearch Scholar, Dept. of Political Science \\ University of Jammu, Jammu
}

\begin{abstract}
Value orientation and wider awareness for betterment of humanity were basic principles of journalism and media for Mahatma Gandhi. These principles provide strength to Indian democracy through modern media or fourth estate. The modern satellite and telecommunication have increased the speed of media activities, communication and dissemination of information. Hence, modern media has become more impact creating than ever earlier. The paradox here is to see how values and morals of Mahatma Gandhi are affecting modern media and mediapersons in an age of speed and satellite communication. This age of media and modern technology was not there in the India at the time of Mahatma Gandhi. The paper aims to discuss the relevanceof Gandhian journalistic approach in modern media business in general and electronic media in particular.
\end{abstract}

Keywords: Electronic, Media, Mahatma Gandhi, Sting Operations, Investigation, Journalism, Values, Morals, Telecommunication, Dissemination, Knowledge Age

\section{Introduction}

"Pen is mightier than sword" old proverb seems to be true even in today's context as the media appears to have gained more strength in the modern society through electronic information dissemination. In this context Chatterjee (2016) pointed out Communication systems are shifting their modes from a mere means of getting information to a platform for marketing.Moreover, earlier forms of modern communication the telegraph, telephone and wireless were strictly under the control of the British government in India before 1947. Even under the independent Government of India, what the British government did with the media during the pre-independence days, continued. Radio was no exceptionmaybe due to this governmental control over media inDoordarshan, TV Networks and All India Radio, the concerned mediapersons were demanding more autonomy.

The relevant bill, in this context received assent of President of India on September 12, 1990 after being unanimously passed by the Parliament. It was finally implemented in November 1997. It was called the PrasarBharti Act. According to this Act, all the property, assets, debt, liabilities, payments of money dues, all legal proceedings involving Akashvani (All India Radio) and Doordarshan were transferred to PrasarBharti to manage their affairs independently. (Government of India, 1997)
Moreover, on International plane, guarantee of freedom of expression and information was recognized as a basic human right in the Universal Declaration of Human Rights adopted by the United Nations (UN) in 1948, the European Convention on Human Rights, the American Convention on Human Rights, and the African Charter on Human and Peoples' Rights. In particular, Article 19 of the 1948 Universal Declaration of Human Rights states: "Everyone has the right to freedom of opinion and expression; this right includes freedom to hold opinions without interference and to seek, receive and impart information and ideas through any media and regardless of frontiers".(United Nations Universal Declaration of Human Rights, 1948). Gandhi has been fighting for all above mentioned rights and freedoms since the beginning of twentieth century

While discussingGandhian perspective on electronic media, quite a few questions and contexts arise here. First, what is the relevance of Gandhian Perspective concerning modern electronic media? Despite Mahatma Gandhi's vast expanse of work in the field of print media journalism through his tabloids namely Indian Opinion, Young India and Harijan, Gandhi lived and functioned apparently in a different age and era. It was mainly the teleprinter, telegram, telephone and radio which could be regarded as expressions of electronic communication during Gandhi's time. 
For Gandhi, regularity, authenticity, selfless service, purposeful information dissemination for social upliftment and national independence were major principles and values underneath his journalism. Profiteering and aims of business were never the priority of journalism for Gandhi. Indeed, he practiced his ideals in journalism. He has, therefore, clearly laid down value orientation and moral bases of journalism extended to modern electronic means of media.(Gandhi, M.K., 1931).In this context Miike (2016) pointed out the importance of dialogue exchange. Therefore this paper aims to discuss the relevance of Gandhian journalistic approach in modern media business in general and electronic media in particular.

\section{Electronic Media after Gandhi}

Electronic media comprises TV channels, blogging and social networking. The old style newspapers and broadcasting has also become electronic in nature as they are equally available on Internet. In others words, almost all journalism, newspapers, telephoning have transformed into electronic media. Projectors, CD Players, Video Players, recorders have all transformed into electronic media. Even Projectors, CD Players, Video Players recorders have all become part of old state technology. The electronic media works its ways in a few seconds only. Distance has little significance in affecting the efficiency of electronic media. The consequences of electronic media communication and information are almost instantaneous. This is why this era of electronic media is also known as knowledge age.

This is an age much beyond the time of Mahatma Gandhi. He could not foresee such rapid changes today. Despite this limitation, Gandhian thought, idea and vision have a touch of timelessness in them because they are highly relevant for setting standard of fundamental policy making to show the path of balanced media operations and performance in this age of social networking.Entertainment, education and information dissemination are three main formats of electronic media in the world today. These three formats are available in the form of movies, videos, slides, specialised lectures and programmes, news exchanges on social networking sites and diversified applications available on mobile network etc.
All these processes work through satellite communication. This is a complex network of electronic technology and knowledge dissemination. There are also value added features in electronic media available currently. Instruments of cameras and spy cameras and also hidden form of long distance satellite focussing and videography/ photography are also there.

All these formats and modes of electronic media have made quest for knowledge a very quick affair. Almost every topic of research and its related material becomes available for study in a jiffy with the push of a button. Thousands of books, encyclopaedia, research journals and topical articles from authentic genuine sources become instantly available for study purposes while sitting at one place. A researcher can do such studies and collect plethora of material from any corner of the world without going anywhere. Similarly, all news and entertainment from all over the world with great details are available to a researcher sitting at home.

\section{Gandhian Views on Automation and Press Freedom}

Descending of knowledge age from late Twentieth century onwards is a highly heartening feature of human life. It is generally understood that Mahatma Gandhi would never approve of such massive technology and automation not only in electronic media but also in modern human life style. Adhikari (2017) echoed the field of communication theory has been witnessing a paradigm shift thereby promoting multicultural and multidisciplinary theorization of communication. Yes, this is true but this truth is far from reality of Gandhian philosophy of life, politics, economics and journalism. Here it is well to see deeper aspects of the Gandhian way of life and the manner in which he used his journalism and communication techniques for the welfare and awareness of the common people of India.

It will be pertinent here to see Gandhi's ideas on mechanisation, automation, journalism and awareness of masses not only in India but also in the world. However, Gandhi did not oppose all machinery or machinery as such. He has stated this position very clearly and categorically. Thus, as early as 1926, he wrote: 
"I am uncompromisingly against all destructivemachinery.But simply tools and instruments and such machinery as saves individual labour and lightens the burden of the million of cottages, I should welcome. He has also stated that he was opposed only to such machinery which was meant to enrich the few at the expense of the many or to displace the useful labour of many".(Young India1926)

The electronic media technology and quick global reach was not there at the time of Mahatma Gandhi's life time. But one thing is clear. It is that Mahatma Gandhi was not against the present form of erstwhile journalism transforming into electronic media. The above mentioned quotation of Mahatma Gandhi and his other writings also prove this. Various views that Gandhi has given in his writings in My Experiments with Truth:An AutoBiography,Collected Works of Mahatma Gandhi, Indian Opinion, Harijan, Young India,Nonviolence in Peace and War and his Hind Swaraj or Indian Home Rulefuther show his fundamental principles about journalism and journalists. These principles can be applied to the functioning of modern electronic media and media persons. In this regard a few quotations from the writings of Mahatma Gandhi are presented here:

"Freedom of the press is a precious privilege that no country can forego". (Gandhi Mahatma, 1958)

"The sole aim of journalism should be service" .(Young India, 1926)

"The newspaper man has become a walking plague. He spreads the contagion of lies". (Gandhi,MK.,Rao, U.R,1963)

"A Journalist'speculiar function is to read the minds of the country and to give definite and fearless expression to that mind". (Gandhi, M.K., 1967)

"Journalism should ever be prosecuted for selfish ends or for the sake of merely earning livelihood or worse still for amassing money". (Gandhi, M.K.,1967)
There is also a well known UNESCO aphorism that says quite like quotation of MahatmaGandhi:

"Since war begins in the minds of men, it is in the minds of men, defence of peace must be constructed". (UNESCO Preamble)

According to article 19(1)(a) all citizens, Press Council of India, Editors Guild of India and Supreme Court of India, and of constitution of India(COI) press and media shall have the right to speech and expression. These fundamental rights are also applicable to electronic media. However, this freedom is not absolute as the article 19(2) also speaks of power of the state to frame law for imposing reasonable restrictions so as to preserve decency, privacy of citizens and integrity and sovereignty of India. The Indian Constitution also provides for certain relevant corresponding duties for all those enjoying fundamental rights and other freedoms in the country (Part1V, Article 51a). These restrictions and freedoms are much more necessary for media in general and electronic media in particular. Security of the State, friendly relations with foreign states, public order, decency, morality and in relation to contempt of court, defamation or incitement to an offence etc all require these restrictions and reasonable freedoms. Electronic media becomes a significant means to streamline such aspects and dynamics of national importance.(Orissa.gov.in/eMagazine/orissarevier/Nov2006/eng.Pdf/87-96.Pdf.)

\section{Gandhi anent Electronic Media}

Miglani and Brar (2017) remarked media organizations are so busy meeting their operational costs and safeguarding profitability, that well-being of employees has become a secondary concern. The cut throat competition has made performance inevitable while concerns like quality of work life of employees and their work place well-being has taken a back seat. But For Gandhi electronic media must serve as an instrument to bring about peaceful conflict resolution and development especially of the downtrodden and poor.During Mahatma Gandhi's time,in order to understand the aims and goals of journalism for Gandhi, media is considered as fourth estate in democratic setup alongwith 
legislature, executive and judiciary. It has been influencing every aspect of human beings life irrespective of place, religion, caste and creed. Its aim to unfold underlying realities of life, media has to work in legally and socially permissible limits in contemporary times. Mahatma Gandhi's ideas continue to evoke interest not only in every human being but also on larger governmental, national and international levels even several decades after his death in 1948.

Gandhi always set high standards for printing words and was of the view that it was the only platform where you can address the mass society in one go and educate them for their multifarious rights. In his Autobiography, he wrote that the sole aimof journalism should be service of Nation and people. The newspaper and media, according to him, has a great power, just as an unchained torrent of water submerges whole countryside and devastates crops even so uncontrolled pen serves to destroy. If the control is from without, it proves more poisonous. It can be profitable only when experienced from within. Hence, highly responsibleform of media coverage is necessary. (Gandhi, M.K., 1956).

His approach to journalism was totally devoid of any self-interest. None of his contemporaries or others afterward used the media so forcefully to ponder over the general issues that concerned the society as he did. He knew the importance of communication and used it to shape the opinion and mobilisation of people. Gandhi was not only a journalist himself as editor of his three tabloid's namelyIndianOpinion, Young India and Harijan but he also had good networking with the national and global community of journalists.Being the fourth pillar of democracy, it is its responsibility to work in the best possible way, to help the nation in adhering to the norms of effective welfare and development of society.(Battacharya, SN., 1998). In this context Chanda (2017) pressed the need of media literacy. The electronic media has progressed from its preliminary stage to the one it has achieved now. From being an alien product, it went on becoming the means adopted by the freedom fighters to realise the dream of a free India. It was the press that went on hand in hand with Raja Ram Mohan Rai, RabindndraNath Tagore, Mahatma Gandhi and Subhash Chandra Bose to voice their call for independence. It was media that conveyed the message of the young revolutionaries to the Britishers. In the present age of knowledge, the most powerful extension and expression of erstwhile traditional media is the electronic media.

\section{Press/Media as Guiding Light}

The might of the press can be understood from the fact that the Father of the Nation called the Press the guiding light which he believed was an excellent means to unite country for strengthening the foundation of the movement against the British.In the contemporary India, Mahatma Gandhi was a great communicator. He adopted 'Mass Line' approach to educate and mobilise millions of people for freedom struggle. In certain places and situations folk form of entertainment and communication facilitated the process of bringing home the concept of national freedom even to simple village folks. His salt Satyagraha was an excellent example of communicating effectively with masses in an age when media was not having existing technology advancement. His methods of fast and vows of silence were also a means of communication with people and masses alongwith a source of self purification. In other words, he aimed to target with one stone, the two birds of communication and self-purification both, successfully and non-violently. Mahatma Gandhi reached millions of people across the world through his communication skills and journalistic approach. He put an ever-lasting impact on Indian national movement through waging a number of nonviolent battles almost single handily. It must be said that that despite being an idealist, Gandhi was not a utopian communicator. His apparently idealism has mostly led to practical success in his experiments with truth, communication and journalism.

\section{Gandhian Criticism of Electronic Media}

He was critical of the tendency of journalists to pick up the bit from here and there and dish them for the purpose of creating sensation. Gandhi regarded this as 'back door journalism'. (Gandhi, M.K., 1972).

Gandhi practised what he preached. Gandhi's tabloids published no advertisement. His approach to journalism was totally devoid of business and profit oriented ambitions. However, with the invention of new 
technology in the field of communication such as TV, Internet, the concept of news reporting was not only limited to newspapers only. Initially there was only one channel, but then with the liberalisationpolicy, there came a wave of private channelswhich also brought incut throat competition. Media started to control the minds of people. It could make people believe what they wanted to state. With the rising competition, the standard of journalism and media started to fall. Media that was a mission before independence grew as a profession after independence and of late, it is being criticised for becoming a business without ethics and without a genuine sense of social responsibility. Gandhi gives utmost priority to public interest for public advantage and benefit.(DuttaSoumya, 2011).

Gandhi was highly critical of journalists and media persons who used their profession as a source of minting money and building finances through advertisement in newspapers and TV channels. For him, journalists should not writeat the back of advertisement. Moreover, the owners of print media and private channels are the owners of either a business establishment or an industrial house or a financial institute. Newsin the hands of these businessmen becomes a commodity. Thereby news which shall be a fair fact becomes "angled" or marketable news. It is widely known that Teleprinter, Telephone and Telegraph were a few electronic media for communication and information exchange in Gandhi's time. These were totally different from what we have today. There is great difference between electronic media during Gandhi's time and media today .Yet, there are the fundamental Gandhian principles for modern media to follow and observe practically.

Modern electronic media is also suffering from rampant corrupt practises in the form of planted stories, politically slanted coverage, working through personal loyalties, paid features and interviews and blackmailing through sting operations. Gandhi does not approve of such activities by media persons. (Coronel, Sheilas, 1991)Thispaid electronic media concomitant with resulting respective loyalty to different political parties and corporate houses necessitates a growing levelling of electronic media in relation to Gandhain ethics and moral values of broadcasting, telecasting and journalism. The electronic media in Indian democracy is avowedly following the Gandhian values which were earlier applied to journalism. Yet, as evidences show especially different TVchannels for news and entertainment are committed with loyalty to one or another corporate house on one hand and different political parties on the other hand. Accordingly, they are following the interest, goals and values of concerned corporate houses, political parties and cultural organisations. For example in India, N18 Network safeguards the interest of MukeshAmbani, while Zee news and India TV are trying to be loyal to B.J.P. and RashtriyaSwavamSevakSangh(RSS). Such loyalties also lead to material benefits to media persons. As such, Rajat Sharma of India TV has been nominated as President of DDCA. None of the electronic media in Indian democracy is following Gandhian principles of impartiality, objectivity and nonprofitability in their acts of dissemination of information. For example Doordarshan mainly protects and promotes the interest of mainly ruling party, NDTV mostly criticises the BJP and NDA. while serving the interest of Indian National Congress and leftist parties. India Today on the other hand favours Indian National Congress.

Election Commission of India while expressing concern for paid news has implemented for the first time the 'Voluntary Code of Ethics for Social Media' and found 1,297 such instances of paid news throughout the country by experts and nodal officials deployed in all constituencies for the purpose. The trend of presenting the advertising content in the guise of news and vice-versa has the potential of damaging the established norms thereby affecting not only the gullible audience but also the financial real estate, stock market, health and industrybesides undermining the democratic process. (Election Commission of India document 2019) Thus ethics have always remained a mainstay when reference to the traditional mass media in India is made. However, the recent technological and business developments have led to deviation from established norms especially under pressure from market forces. The influence is so evident that the explicit distinction between 'News' and 'Advertisement' is very difficult to make out. 
Gandhi does not approve of such activities by media persons. On the other hand the Gandhian perspective on media and journalism rests on following principles put in a nutshell:

a. Objectivity

b. Truth must prevail because truth has no fear

c. Fearlessness

d. Social optimal information dissemination

e. Value orientation or ethical journalism

f. Against the concept of paid news

g. Journalists and mediapersonsipso facto in electronic media also must not have the right to perform on the back of advertisement posters and electronic commercial

h. Media persons therefore must be dedicated to thewelfare of the poor and for the nation and also for the world

i. Media and journalism must run on no profit no loss basis

j. Come what may, regularityin journalism, newspapers and media programmes must be maintained. Resource crunch cannot be a pretext to postpone the regular publication or filming of news stories and programmes

\section{Purity of Means and Ends}

Gandhi always believed that media should educate and inspire the masses for a greater cause. According to him, media should follow high ethical and moral standards by following value based journalism. However, the TRP based craze in rating has rendered media into a huge challenge to face for Indian democracy. Gandhianideas of purity of means and ends when applied to media set the narrative for media. Media free from business vendetta can only enjoy the freedom as well as its 'sanity'. In order to have fair and objective reporting of electronic media, the Press Council of India, and Editors Guild of India, seemingly on Gandhian lines, have prescribed norms of Code of Conduct for press and media in India:
a. Accuracy
b. Pre-publication verification
c. Caution against defamatory writings
d. Paramount National interest
e. Norms of investigating journalism
f. Fearlessness and social responsibility
g. Keeping away from exaggeration, distortion and sensationalism

h. All creeds and communities must be shown equal respect. (Sachindananda, K.S.,2007)

Although, the Press Council of India and Editor Guild of India have laid down distinctive yardsticks of news writings, these 'Canons of Journalism' have come under serious threat in recent times. Various news organisations and reporters forget the 'Code of Ethics' in the acquisition as well as dissemination of information to the public. There can be various reasons for such nonobjective reporting like sensationalism, increasing readership and viewship, pressure from proprietors, coercion from powerful and useful news sources and selective diffusion and retention of news items by journalists due to one or several reasons. For instance, 'the principle of limitation of harm' is a rule set for the journalistic code of ethics which involves deletion of certain details from news reports like withholding the names of minor children, crime victims as well as certain informative details which are irrelevant or crucial and its exposure might harm someone's reputation or create hurdles in the process of investigation. In theAarushi murder case of 2008 the media intensely scrutinisedthe case with its elaborate coverage. This forced the CBI to seek the help of Supreme Court in order to curtail media from sensationalizing. Justice AltamasKabir stated,"We are asking the press not to sensationalise something which affects reputations". (ibnlive.com/news/aarushiHemrajMurder)This case became sensational on Internet and private television channels as well. As a result the masses attentiontowards the case widened and it became a topic of public interest in general. Thus, the need aroused to differentiate between 'public interest' and "interest of the public". They both are relatively two different things as the first is concerned with the issues relating to the benefit of the public and the second is concerned with the issues which the public may find interesting. Thus, the issues which belong to the second category should be taken care of judiciously so that they might not harm the privacy of the concerned or impair thereputation. It is therefore the primary responsibility of the mass media to be highly alert and vigilant

The Gandhian 'ends and means' relates to another example of electronic media today 
'Sting Operation' is another secret weapon often used by press as well as television media. There is no denying to the fact that though sting operations have often exposed the truth by making startling revelations which may be beneficial for the society but certain critics have put forth an interrogative mark on the ethical veracity of such operations by mediapersons. Though these sting operations bring the truth to forefront by exposing certain individuals and such exposure may make the masses aware and alert but some other vices like falsehood, biased and prejudiced exposure are associated with sting operations which provide little opportunity to the victims to defend themselves in public. Certain questions on ethical propriety are associated with sting operations.These operations are indeed one sided affairs. In this way, they are a major scar on journalistic code of fairness and impartiality. For instance, "Operation West End" organised by Tehelka and numerous other instances their revelations created quite a stir regarding the ethical issues associated with such exposures, but failed to give way an alternative to investigative journalism.

\section{Conclusion}

Despite various pejorative aspects of modern electronic media, the strength of democracy is drawn to a large extent from journalism and electronic media and the extent of freedom of expression available to media persons. The more the exposure, the deeper and longer lastingis democracy. There is mutuality between democracy, journalism and electronic media. None can go alone. They are mutually interdependent. This is evertruer in this age of information and knowledge dissemination. It is truth that prevails for Mahatma Gandhi. It means objective reporting and dissemination of news and knowledge.This necessity of objectivity is bound by freedom of expression within given ambit of social cohesion and ethics. Therefore, the Gandhian journalism and its basic principles observe rule of law and established social, political traditions and norms of propriety. Gandhian ethics are very clear on journalistic practices extendable to electronic media and media persons. Thus, without the observance of the basic principles or Gandhian perspective on electronic media, the purpose of democracy cannot be fulfilled. Real power to citizens in a democracy can percolate down mainly through the Gandhian principles of journalism .Gandhi believed that it is sincerity, sympathy and charity that touch the heart more than anything else. Gandhi as a developmental journalist showed an example to the present day media of how to practice ethics based on developmental journalism.

The basic principles of Gandhian journalism applied to modern electronic media are being challenged by corporatisation of media houses and globalised structures in the market placesIn this atmosphere paid news and propaganda have been realthreat for ethical journalism. For a few apparent exceptions like sting operations etc., media in India is going quite in opposite direction of what Gandhi considers to be ethics of media and journalism. Most of the media and TV channels are owned by the corporate giants like MukeshAmbani and Subash Chandra and these giants are titled towards one or the other politicalparty or regime. Accordingly, news and other programmes clandestinely(become mouth pieces of ideology and acts of political party) pose a great threat to credibility and objectivity of electronic media The real question is about the practical possibility of applying Gandhian ethics of journalism to modern media. Is it really possible? Will modern media be able tosustain itself if it really goes in the direction of Gandhian way?

\section{REFERENCES}

Bhattacharya, S.N. (1998).Mahatma Gandhi, The Journalist.Bombay:AsiaPublishing

Collected Works of Mahatma Gandhi, (1967).

Collected Works of Mahatma Gandhi, (1967).

Coronel, Sheilas.(1991). The Role of Media in Deepening Democracy. Cambridge:Cambridge University Press

Chatterjee, S.(2016). Digital Culture: A Paradigm shift in Communication Perspective In Post Globalised World. Journal of Content, Community \&Communication.3(2).pp: 44-49

Dutta,Soumya.(2011).Social Responsibility of Media and Indian Democracy.Global Media Journal, Indian Edition, Summer Issue,

Election Commission of India Report (2019).

Gandhi, Mahatma.(1931).Hind Swaraj.Ahmedabad:Navajivan Press

Y, Miike.(2016). Asian Communication Studies at the Crossroads: A view to the future from 
an Asiacentric Framework.Journal of Content, Community \&Communication.3(2).p:1

Gandhi, Mahatma.(1956).An Autobiography or The Story of my Experiment with Truth.Ahmedabad: Navjivan publishing house.

Gandhi, Mahatma.(1958). India of my Dreams.New Delhi: Raj Pal and Sons.

Gandhi, Mahatma (1972).Satyagraha in South Africa. Ahmadabad: Navajivan Publishing House.

Adhikary, N,M.(2017).Towards Reconciliation of eastern and western philosophy: A special reference to communication theory.Journal of Content, Community \&Communication.5(3).pp:16

Government of India, Prasarbharti.gov.in/ corporate/pb\%20act/pages/defaultaspx.,1997.

Harijan, 22June 1935.

ibnlive.com/news/aarushi-hemraj Murder.

Murthy, Sachindananda.(2007). Code of Practice for Journalism. New Delhi: Editors Guild of India,
Miglani, N and Brar, P.(2017).Mapping the Work-Home Conflict of Indian Fashion \& Lifestyle Journalists.Journal of Content, Community ECommunication.5(3).pp:7-14

A Study of Punjab, Haryana and Himachal Pradesh Bureaus

Rao,UR.,Gandhi,Mahatma.(1963). Minds of Mahatma Gandhi.Ahmedabad:

NavjivanPublishing.

Chanda, N. (2017). Media Education and Media Literacy: Conceptualising the significance of critical and twenty-first-century literacies in media education. Journal of Content, Community \& Communication. 5(3). pp: 22-25

UNESCO Preamble Orissa.gov.in/eMagazine/orissarevier/Nov2006/eng.Pdf/87-96.Pdf.

United Nations Universal Declaration of Human Rights 1948; sisu http://www.jus.um.no/s.so (this copy) 1948.

Young India, 17 June 1926.

Young India, 17 June 1926. 